\title{
Soil Test Based Fertilizer Prescriptions Through Inductive Cum Targeted Yield Model for Transgenic Cotton on Inceptisol
}

\author{
S. Praveena Katharine* ${ }^{1}$, R. Santhi ${ }^{1}$, S. Maragatham ${ }^{1}$, R.Natesan ${ }^{1}$, \\ V.Ravikumar ${ }^{2}$ and Pradip Dey ${ }^{3}$ \\ ${ }^{I}$ Department of Soil Science and Agricultural Chemistry, Tamil Nadu Agricultural University, Coimbatore, India. \\ ${ }^{2}$ Agricultural Engineering College and Research Institute, Kumulur, Tamil Nadu, India. \\ ${ }^{3}$ Indian Institute of Soil Science, Bhopal, Madhya Pradesh, India.
}

\begin{abstract}
Studies on Soil Test Crop Response based Integrated Plant Nutrition System (STCR - IPNS) were conducted adopting the Inductive cum Targeted yield model, on Vertic Ustropept of Tamil Nadu, Southern India during 2011 - 2013 in order to develop fertilizer prescriptions through IPNS for the desired yield targets of transgenic cotton under drip fertigation. The basis for making the fertilizer prescriptions viz. nutrient requirement $(N R)$, contribution of nutrients from soil (Cs), fertilizer (Cf) and farmyard manure (Cfym) were computed using the field experimental data. Making use of these basic parameters, the fertilizer prescription equations (FPEs) were developed under NPK alone and under IPNS for the desired yield targets of cotton for a range of soil test values. The quantity of fertilizers contributed by the application of farmyard manure was assessed. The deviation recorded in the achievement of targets aimed was within the range of \pm 10 per cent $(90-110 \%)$ proving the validity of the FPEs. Thus the Inductive cum Targeted yield model used to develop fertilizer prescription equations provides a strong basis for soil fertility maintenance consistent with high productivity and efficient nutrient management in "Precision Farming" for sustainable and enduring Agriculture.
\end{abstract}

Key words: Fertilizer prescription equations, Inceptisol, STCR-IPNS, transgenic cotton, yield target.

\section{Introduction}

Cotton (Gossypium sp.) popularly known as 'White Gold' is a premier cash crop playing a key role in economical and social status of the world. Cotton lint, an important textile fiber comprises about $35 \%$ of total world fiber use (USDA, ERS, 2011)[1]. The area under transgenic cotton is increasing geometrically. However, the rising prices for fertilizers and other inputs are of increasing concern for farmers as fertilizer management has an important impact on the profitability of cotton production (Bazen et al., 2007)[2]. Also, cotton cultivation of late is proving to be less remunerative enterprise primarily because of high cost of production due to indiscriminate use of pesticides and fertilizers (Tayade and Dhoble, 2010)[3]. In the prevailing regime of widespread negative nutrient balances, it is difficult to expect depleted soils to support bumper crops or yield high growth rates, even in a superior hybrid or a genetically modified crop. Sustainability of agricultural systems has become an important issue in developing countries, including India. Over-exploitation of soils over many decades has resulted in the exhaustion of the agricultural production systems and steadily declining productivity has been noticed in long term experiments in Asia (Bhandari et al., 2002[4]; Ladha et al., 2003[5]; Manna et al., 2005[6]). The decision on fertilizer use requires knowledge of the expected crop yield response to nutrient application, which is a function of crop nutrient needs, supply of nutrients from indigenous sources, and the fate of the fertilizer applied (Dobermann et al., 2003)[7].

In the era of precision agriculture, the concept of 'Soil test based fertilizer recommendation' harmonizes the much debated approaches namely, 'Fertilizing the soil' versus 'Fertilizing the crop' ensuring for real balance (not apparent balance) between the applied fertilizer nutrients among themselves and with the soil available nutrients. Truog (1960)[8] illustrated the possibility of 'Prescription method' of fertilizer use for obtaining high yields of corn using empirical values of nutrient availability from soil and fertilizer. However, Ramamoorthy and his associates established during 1965-67 the theoretical basis and field experimental proof and validation for the fact that Liebig's Law of Minimum of Plant nutrition (Liebig, 1855)[9] operates equally well for $\mathrm{N}, \mathrm{P}$ and $\mathrm{K}$ for the high yielding varieties of wheat, rice and pearl millet, although it is generally believed that this law is valid for $\mathrm{N}$ and not for $\mathrm{P}$ and $\mathrm{K}$ which were supposed to follow the percentage sufficiency concept of Mitscherlich and Baule and Mitscherlich and Bray. Among the various methods of formulating fertilizer recommendations, the one based on yield targeting is unique in the sense that this method not only indicates soil test based fertilizer dose but also the level of yield the farmer can hope to achieve, if good cultivation package is followed (Velayutham, 1979)[10].

In the "Inductive Approach" of STCR field experimentation, all the needed variation in soil fertility level is obtained not by selecting soils at different locations as in earlier agronomic trials, but by deliberately 
creating it in one and the same field experiment in order to reduce heterogeneity in the soil population (types and units) studied, management practices adopted and climatic conditions. Ramamoorthy and Velayutham (1971[11], 1972[12] \& 1974[13]) have elaborated this Inductive approach and the STCR field design, which is also quoted by Black (1993)[14]. The experimental data can be used for developing fertilizer recommendations for maximum yield and profit and for desired yield targets of crops. Field specific balanced amounts of N, P and $\mathrm{K}$ were prescribed based on crop based estimates of the indigenous supply of $\mathrm{N}, \mathrm{P}$ and $\mathrm{K}$ and by modelling the expected yield response as a function of nutrient interaction (Dobermann and White 1998[15]; Witt et al., 1999[16]). In an investigation on soil test crop response on garlic in medium black calcareous soils of Saurashtra region of Gujarat, Sakarvadia et al. (2012)[17] found yield targeting approach effective in soil fertility build up. Khosa et al. (2012)[18] also reported the superiority of the target yield concept over other practices for different crops as it gave higher yields and optimal economic returns. The specific yield equation based on soil health besides ensuring sustainable crop production also steers the farmers towards economic use of costly fertilizer inputs depending on their financial status and prevailing market price of the crop under consideration (Bera et al., 2006)[19].

The fertilizer prescription equations developed using this model can be applied to Inceptisols of all tropical regions by substituting the soil nutrient status of the particular field. Moreover, the methodology adopted in the present investigation can very well be used to derive fertilizer prescription equations for any field or horticultural crop (except perennial crops) on any soil series. On account of the above facts, the present investigation was contemplated in transgenic cotton on Inceptisol under drip fertigation so as to elucidate the significant relationship between soil test values and crop response to fertilizers, to develop fertilizer prescription equations under IPNS for desired yield target of transgenic cotton and to test verify the validity of fertilizer prescription equations developed for transgenic cotton under drip fertigation.

\section{Materials And Methods}

Studies on Soil Test Crop Response based Integrated Plant Nutrition System (STCR - IPNS) were conducted adopting the Inductive cum Targeted yield model, on a Vertic Ustropept of Tamil Nadu, India. This study comprised of three field experiments in three phases viz., fertility gradient experiment with fodder maize var.CO1 (Phase I), test crop experiment with transgenic cotton RCH-530 BGII (Phase II) and test verification trial with transgenic cotton RCH-530 BGII (Phase III). The details of the field experiments carried out and methods of analysis of soil and plant samples and the methodology followed in the development of prescription equations are presented below.

\subsection{Basic concept}

The methodology adopted in this study is the prescription procedure outlined by Truog (1960) and modified by Ramamoorthy et al. (1967)[20] as "Inductive cum Targeted yield model" which provides a scientific basis for balanced fertilization and balance between applied nutrients and soil available nutrients forms. Operational range of variation in soil fertility was created deliberately to generate data covering appropriate range of values for each controllable variable (fertilizer dose) at different levels of uncontrollable variable (soil fertility) which could not be expected to occur at one place normally. Hence, in order to create fertility variations in the same field, a gradient experiment was conducted prior to the test crop experiment to reduce the heterogeneity in the soil population studied, management practices adopted and climatic conditions prevailing.

\subsection{Study site and soil description}

The field experiments were conducted at the Eastern block of TNAU farm, Coimbatore, Tamil Nadu, Southern India on Inceptisol (Vertic Ustropept). The farm is located in the Western agro climatic zone of Tamil $\mathrm{Nadu}$ at $11^{\circ} 12^{\prime}$ North latitude and $77^{\circ} 03^{\prime}$ 'East longitude at an altitude of $426.74 \mathrm{~m}$ above MSL. The gradient and test crop experiments were conducted during October 2011 to April 2012 and the test verification trial during August 2012 to March 2013. The soil of the experimental field belongs to Periyanaickenpalayam series taxonomically referred to as Vertic Ustropept exhibiting clay loam texture, moderately alkaline reaction $(\mathrm{pH}$ 8.4) and non - saline conditions (EC $\left.0.17 \mathrm{dS} \mathrm{m}^{-1}\right)$. The initial soil fertility status showed low organic carbon (4.7 $\left.\mathrm{g} \mathrm{kg}^{-1}\right)$, low available $\mathrm{N}\left(225 \mathrm{~kg} \mathrm{ha}^{-1}\right)$, medium available $\mathrm{P}\left(19.9 \mathrm{~kg} \mathrm{ha}^{-1}\right)$, high available $\mathrm{K}\left(570 \mathrm{~kg} \mathrm{ha}^{-1}\right)$. The available $\mathrm{Zn}, \mathrm{Cu}$ and $\mathrm{Mn}$ were in the sufficient range $\left(1.29,1.94\right.$ and $11.39 \mathrm{mg} \mathrm{kg}^{-1}$ respectively) while available $\mathrm{Fe}$ was in the deficient range $\left(3.34 \mathrm{mg} \mathrm{kg}^{-1}\right)$. The total $\mathrm{N}, \mathrm{P}$ and $\mathrm{K}$ contents of the soil was $0.13,0.09$ and 0.45 per cent respectively. The $\mathrm{P}$ and $\mathrm{K}$ fixing capacities of the soil were $100 \mathrm{~kg} \mathrm{ha}^{-1}$.

\subsection{Treatment structure and soil and plant analysis}

The field experiments viz., fertility gradient experiment with fodder maize (var. CO 1), the test crop experiment with transgenic cotton ( $\mathrm{RCH} 530 \mathrm{BGII})$ and the test verification trial with transgenic cotton $(\mathrm{RCH}$ 530 BGII) were conducted at TNAU Farm, Coimbatore on Inceptisol. The details of crops and important 
cultural operations carried out in the experiments are furnished in Table 1. The approved treatment structure and lay out design as followed in the All India Coordinated Research Project for Investigations on Soil Test Crop Response Correlation (AICRP-STCR) based on "Inductive cum Targeted yield model" (Ramamoorthy et al., 1967) was adopted in the present investigation.

\subsubsection{Gradient experiment}

In the gradient experiment, operational range of variation in soil fertility was created deliberately. For this purpose, the experimental field was divided into three equal strips, the first strip received no fertilizer $\left(\mathrm{N}_{0} \mathrm{P}_{0} \mathrm{~K}_{0}\right)$, the second and third strips received one $\left(\mathrm{N}_{1} \mathrm{P}_{1} \mathrm{~K}_{1}\right)$ and two $\left(\mathrm{N}_{2} \mathrm{P}_{2} \mathrm{~K}_{2}\right)$ times the standard dose of $\mathrm{N}$, $\mathrm{P}_{2} \mathrm{O}_{5}$ and $\mathrm{K}_{2} \mathrm{O}$ respectively and a gradient crop of fodder maize (var.CO 1) was grown. Eight pre-sowing and post-harvest soil samples were collected from each fertility strip and analysed for alkaline $\mathrm{KMnO}_{4}-\mathrm{N}$ (Subbiah and Asija, 1956)[21], Olsen -P (Olsen et al., 1954)[22] and $\mathrm{NH}_{4} \mathrm{OAc}-\mathrm{K}$ (Stanford and English, 1949)[23]. At harvest, plant samples were collected, processed and analyzed for N (Humphries, 1956)[24], P and K contents (Jackson, 1973)[25] and NPK uptake was computed.

\subsubsection{Test crop experiment}

After confirming the establishment of fertility gradients in the experimental field, in the second phase of the field experiment, each strip was divided into 24 plots, and initial soil samples were collected from each plot and analyzed for alkaline $\mathrm{KMnO}_{4}-\mathrm{N}$, Olsen-P and $\mathrm{NH}_{4} \mathrm{OAc}-\mathrm{K}$. The experiment was laid out in a fractional factorial design comprising twenty four treatments and the test crop experiment with cotton was conducted with four levels each of $\mathrm{N}\left(0,60,120\right.$ and $\left.180 \mathrm{~kg} \mathrm{ha}^{-1}\right), \mathrm{P}_{2} \mathrm{O}_{5}\left(0,30,60\right.$ and $\left.90 \mathrm{~kg} \mathrm{ha}^{-1}\right)$ and $\mathrm{K}_{2} \mathrm{O}\left(0,40,80\right.$ and $\left.120 \mathrm{~kg} \mathrm{ha}^{-1}\right)$ and three levels of FYM $\left(0,6.25\right.$ and $\left.12.5 \mathrm{t} \mathrm{ha}^{-1}\right)$. The experiment was conducted as per the approved guidelines of AICRP-STCR and fertilizer recommendations were developed.

The IPNS treatments viz., NPK alone, NPK+FYM @ $6.25 \mathrm{t} \mathrm{ha}^{-1}$ and NPK+FYM @ $12.5 \mathrm{t} \mathrm{ha}^{-1}$ were superimposed across the strips. There were 21 fertilizer treatments along with three controls which were randomized in each strip in such a way that all the treatments occurred in both the directions. The treatment structure and layout are given in Fig.1. The test crop cotton was sown with a spacing of $120 \mathrm{~cm}$ x $90 \mathrm{~cm}$. Routine cultural operations were followed periodically. The sources of nutrients used in fertigation were urea, single super phosphate and muriate of potash. The crop was grown to maturity, harvested and plot wise seed cotton yield was recorded. The seed cotton, plant and post-harvest soil samples were collected from each plot. As done in gradient crop, the soil and plant samples were processed and analyzed and NPK uptake by cotton was computed using the dry matter yield.

\subsection{Basic parameters for fertilizer prescription equations}

Making use of data on the yield of cotton, total uptake of $\mathrm{N}, \mathrm{P}$ and $\mathrm{K}$, initial soil test values for available $\mathrm{N}, \mathrm{P}$ and $\mathrm{K}$ and doses of fertilizer $\mathrm{N}, \mathrm{P}_{2} \mathrm{O}_{5}$ and $\mathrm{K}_{2} \mathrm{O}$ applied, the basic parameters viz., nutrient requirement (NR), contribution of nutrients from soil (Cs), fertilizer (Cf) and farmyard manure (Cfym) were calculated as outlined by Ramamoorthy et al. (1967).

\subsubsection{Nutrient Requirement (NR):}

$\mathrm{kg}$ of $\mathrm{N} / \mathrm{P}_{2} \mathrm{O}_{5} / \mathrm{K}_{2} \mathrm{O}$ required per quintal $\left(100 \mathrm{~kg}\right.$ ) of seed cotton production, expressed in $\left(\mathrm{kg} \mathrm{q}^{-1}\right)$.

$\mathrm{NR}=\left(\right.$ Total uptake of $\mathrm{N}$ or $\mathrm{P}_{2} \mathrm{O}_{5}$ or $\left.\mathrm{K}_{2} \mathrm{O}\left(\mathrm{kg} \mathrm{ha}^{-1}\right)\right) /$ Seed cotton yield $\left(\mathrm{q} \mathrm{ha}{ }^{-1}\right)$

\subsubsection{Per cent contribution of nutrients from soil to total nutrient uptake (Cs):}

$\mathrm{Cs}=\left[\left(\right.\right.$ Total uptake of $\mathrm{N}$ or $\mathrm{P}_{2} \mathrm{O}_{5}$ or $\mathrm{K}_{2} \mathrm{O}$ in control plot $\left.\left(\mathrm{kg} \mathrm{ha}^{-1}\right)\right) /$ (Soil test value for available Nor $\mathrm{P}_{2} \mathrm{O}_{5}$ or $\mathrm{K}_{2} \mathrm{O}$ in control plot $\left.\left.\left(\mathrm{kg} \mathrm{ha}^{-1}\right)\right)\right] * 100$

\subsubsection{Per cent contribution of nutrients from fertilizer to total uptake (Cf):}

$\mathrm{Cf}=\left\{\left[\left(\right.\right.\right.$ Total uptake of $\mathrm{N}$ or $\mathrm{P}_{2} \mathrm{O}_{5}$ or $\mathrm{K}_{2} \mathrm{O}$ in treated plot $\left.\left(\mathrm{kg} \mathrm{ha}^{-1}\right)\right)$ - (Soil test value for available $\mathrm{N}_{0}$ or $\mathrm{P}_{2} \mathrm{O}_{5}$ or $\mathrm{K}_{2} \mathrm{O}$ in control plot $\left(\mathrm{kg} \mathrm{ha}^{-1}\right) *$ Average Cs) $] /$ Fertilizer $\mathrm{N}$ or $\mathrm{P}_{2} \mathrm{O}_{5}$ or $\mathrm{K}_{2} \mathrm{O}$ applied $\left.\left(\mathrm{kg} \mathrm{ha}^{-1}\right)\right\} * 100$

\subsubsection{Percent contribution of nutrients from organics to total uptake (Co)}

\subsubsection{Percent contribution from FYM (Cfym):}

Cfym $=\left\{\left[\left(\right.\right.\right.$ Total uptake of $\mathrm{N}$ or P or K in FYM treated plot $\left.\left(\mathrm{kg} \mathrm{ha}^{-1}\right)\right)-($ Soil test value for available $\mathrm{N}$ or $\mathrm{P}$ or K in FYM treated plot $\left(\mathrm{kg} \mathrm{ha}^{-1}\right) *$ Average Cs)] / Nutrient N/P/K added through FYM $\left.\left(\mathrm{kg} \mathrm{ha}^{-1}\right)\right\} * 100$

These parameters were used for developing fertilizer prescription equations for deriving fertilizers doses, and the soil test based fertilizer recommendations were prescribed in the form of a ready table for desired yield target of cotton under NPK alone as well as under IPNS. 


\subsection{Fertilizer prescription equations}

Making use of these parameters, the fertilizer prescription equations (FPEs) were developed for cotton as furnished below.

\subsubsection{Fertilizer nitrogen $(\mathrm{FN})$ :}

$\mathrm{FN}=\{[(\mathrm{NR} /(\mathrm{Cf} / 100)) * \mathrm{~T}]-[(\mathrm{Cs} / \mathrm{Cf}) * \mathrm{SN}]\}$

$\mathrm{FN}=\{[(\mathrm{NR} /(\mathrm{Cf} / 100)) * \mathrm{~T}]-[(\mathrm{Cs} / \mathrm{Cf}) * \mathrm{SN}]-[(\mathrm{Cfym} / \mathrm{Cf}) * \mathrm{ON}]\}$

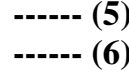

2.5.2. Fertilizer phosphorus $\left(\mathrm{FP}_{2} \mathrm{O}_{5}\right)$ :

$\mathrm{FP}_{2} \mathrm{O}_{5}=\{[(\mathrm{NR} /(\mathrm{Cf} / 100)) * \mathrm{~T}]-[(\mathrm{Cs} / \mathrm{Cf}) * 2.29 \mathrm{SP}]\}$

$\mathrm{FP}_{2} \mathrm{O}_{5}=\{[(\mathrm{NR} /(\mathrm{Cf} / 100)) * \mathrm{~T}]-[(\mathrm{Cs} / \mathrm{Cf}) * 2.29 \mathrm{SP}]-[(\mathrm{Cfym} / \mathrm{Cf}) * 2.29 \mathrm{OP}]\}$

\subsubsection{Fertilizer potassium $\left(\mathrm{FK}_{2} \mathrm{O}\right)$ :}

$\mathrm{FK}_{2} \mathrm{O}=\{[(\mathrm{NR} /(\mathrm{Cf} / 100)) * \mathrm{~T}]-[(\mathrm{Cs} / \mathrm{Cf}) * 1.21 \mathrm{SK}]\}$

$\mathrm{FP}_{2} \mathrm{O}_{5}=\{[(\mathrm{NR} /(\mathrm{Cf} / 100)) * \mathrm{~T}]-[(\mathrm{Cs} / \mathrm{Cf}) * 2.29 \mathrm{SK}]-[(\mathrm{Cfym} / \mathrm{Cf}) * 1.21 \mathrm{OK}]\}$

where, $\mathrm{FN}, \mathrm{FP}_{2} \mathrm{O}_{5}$ and $\mathrm{FK}_{2} \mathrm{O}$ are fertilizer $\mathrm{N}, \mathrm{P}_{2} \mathrm{O}_{5}$ and $\mathrm{K}_{2} \mathrm{O}$ in $\mathrm{kg} \mathrm{ha}^{-1}$, respectively; NR is nutrient requirement $\left(\mathrm{N}_{\text {or }} \mathrm{P}_{2} \mathrm{O}_{5}\right.$ or and $\left.\mathrm{K}_{2} \mathrm{O}\right)$ in $\mathrm{kg} \mathrm{q}^{-1}$, Cs is per cent contribution of nutrients from soil, $\mathrm{Cf}$ is per cent contribution of nutrients from fertilizer, Cfym is percent contribution of nutrients from FYM, T is the yield target in $\mathrm{q} \mathrm{ha}^{-1} ; \quad \mathrm{SN}, \mathrm{SP}$ and SK respectively are alkaline $\mathrm{KMnO}_{4}-\mathrm{N}$, Olsen-P and $\mathrm{NH}_{4} \mathrm{OAc}-\mathrm{K}$ in kg ha ${ }^{-1}$ and $\mathrm{ON}, \mathrm{OP}$ and $\mathrm{OK}$ are the quantities of N, P and K supplied through FYM in $\mathrm{kg} \mathrm{ha}^{-1}$.

These equations serve as a basis for predicting fertilizer doses for specific yield targets $(\mathrm{T})$ of cotton for varied soil available nutrient levels.

\section{Results And Discussion}

\subsection{Seed cotton yield, Uptake and Initial available NPK status}

The range and mean values (Table 2) indicated that the seed cotton yield ranged from $1082 \mathrm{~kg} \mathrm{ha}^{-1}$ in absolute control to $3405 \mathrm{~kg} \mathrm{ha}^{-1}$ in $\mathrm{N}_{180} \mathrm{P}_{90} \mathrm{~K}_{80}+$ FYM @ $12.5 \mathrm{t} \mathrm{ha}^{-1}$ of strip II with mean values of 2146,2691 and $2803 \mathrm{~kg} \mathrm{ha}^{-1}$, respectively in strips I, II and III. The N uptake by cotton varied from 43.2 to $152.9 \mathrm{~kg} \mathrm{ha}^{-1} ; \mathrm{P}$ uptake from 8.69 to $47.7 \mathrm{~kg} \mathrm{ha}^{-1}$ and $\mathrm{K}$ uptake from 52.2 to $140.2 \mathrm{~kg} \mathrm{ha}^{-1}$ in strips I, II and III, respectively.

The data on initial soil test values of cotton revealed that, the mean $\mathrm{KMnO}_{4}-\mathrm{N}$ was 213,238 and $255 \mathrm{~kg}$ ha $^{-1}$, respectively in strips I, II and III. The mean Olsen-P values were 16.4, 30.4 and 38.0 ,kg ha ${ }^{-1}$ respectively in strips I to III and the mean $\mathrm{NH}_{4} \mathrm{OAc}-\mathrm{K}$ values were 554, 589 and $609 \mathrm{~kg} \mathrm{ha}^{-1}$ in strips I, II and III, respectively (Table 2).

The existence of operational range of soil test values for available $\mathrm{N}, \mathrm{P}$ and $\mathrm{K}$ status in the present investigation was clearly depicted from the initial soil available nutrient status and variations in the seed cotton yield of cotton and NPK uptake, which is a prerequisite for calculating the basic parameters and developing fertilizer prescription equations for calibrating the fertilizer doses for specific yield target of cotton.

\subsection{Response of transgenic cotton to fertilizer $\mathrm{N}, \mathrm{P}_{2} \mathrm{O}_{5}$ and $\mathrm{K}_{2} \mathrm{O}$}

Optimisation of nutrients is largely based on the response of the crop to applied fertiliser nutrients. Application of N, $\mathrm{P}$ and $\mathrm{K}$ had a significant effect on plant growth and yield. The response of cotton to different levels of fertilizer $\mathrm{N}, \mathrm{P}_{2} \mathrm{O}_{5}$ and $\mathrm{K}_{2} \mathrm{O}$ were assessed in terms of response ratio (RR). There was a progressive increase in response for $\mathrm{N}, \mathrm{P}_{2} \mathrm{O}_{5}$ and $\mathrm{K}_{2} \mathrm{O}$ levels from $\mathrm{N}_{60}$ to $\mathrm{N}_{180}, \mathrm{P}_{30}$ to $\mathrm{P}_{90}$ and $\mathrm{K}_{40}$ to $\mathrm{K}_{120}$, respectively and the highest $\mathrm{RR}$ of $\mathrm{N}$ recorded was 5.30 at $\mathrm{N}_{180}$. Similar trend was observed for phosphorus and potassium with the highest $R R$ of 4.60 and 2.95 observed at $\mathrm{P}_{90}$ and $\mathrm{K}_{120}$ respectively (Table 3).

\subsection{Basic parameters (Table 4)}

In the targeted yield model, The basic parameters for developing fertilizer prescription equations for cotton are (i) nutrient requirement (NR) in kg per quintal of seed cotton, per cent contribution of available NPK from soil (Cs), fertilizers (Cf) and farmyard manure (Cfym). Making use of data on the yield of cotton, total uptake of $\mathrm{N}, \mathrm{P}$ and $\mathrm{K}$, initial soil test values for available $\mathrm{N}, \mathrm{P}$ and $\mathrm{K}$ and doses of fertilizer $\mathrm{N}, \mathrm{P}_{2} \mathrm{O}_{5}$ and $\mathrm{K}_{2} \mathrm{O}$ applied, the basic parameters were computed.

\subsubsection{Nutrient requirement of transgenic cotton}

Application of adequate amount of nutrients is a pre-requisite for exploiting genetic potential of any crop. Cotton which is a heavy feeder exhibits vigorous growth and dry matter production (DMP) and is responsive to application of fertilizers. Nutrient requirement to produce one quintal (100 kg) of seed cotton was $4.43 \mathrm{~kg}$ of N, $2.20 \mathrm{~kg}$ of $\mathrm{P}_{2} \mathrm{O}_{5}$ and $4.83 \mathrm{~kg}$ of $\mathrm{K}_{2} \mathrm{O}$. In the present investigation, the requirement of $\mathrm{K}_{2} \mathrm{O}$ was higher which is followed by $\mathrm{N}$ and $\mathrm{P}_{2} \mathrm{O}_{5}$. The requirement of $\mathrm{K}_{2} \mathrm{O}$ was 1.09 times higher than $\mathrm{N}$ and 2.20 times 
higher than $\mathrm{P}_{2} \mathrm{O}_{5}$. The major demand for $\mathrm{K}$ by the plant comes at boll set. Even in soils rated high in available $\mathrm{K}$, in-season $\mathrm{K}$ shortage can develop due to the heavy demand during rapid boll set and fill (Gormus and Yucel, 2002)[26].

\subsubsection{Per cent contribution of nutrients from soil (Cs) and fertilizers (Cf) to total uptake of cotton}

The per cent contribution of nutrients from soil (Cs) to the total uptake was computed from the absolute control plots and it expresses the capacity of the crop to extract nutrients from the soil. In the present study, it was found that the soil has contributed 24.65 per cent of available N, 48.95 per cent of available $\mathrm{P}$ and 11.06 percent of available $\mathrm{K}$ respectively towards the total $\mathrm{N}, \mathrm{P}$ and $\mathrm{K}$ uptake by cotton. The nutrient contribution of the soil to transgenic cotton was relatively higher for $\mathrm{P}_{2} \mathrm{O}_{5}$ as compared to that by $\mathrm{N}$ and $\mathrm{K}_{2} \mathrm{O}$. With regard to $\mathrm{N}$ and $\mathrm{K}_{2} \mathrm{O}$, comparatively lower $\mathrm{Cs}$ was recorded which might be due to the preferential nature of cotton towards the applied $\mathrm{N}$ and $\mathrm{K}_{2} \mathrm{O}$ than the native $\mathrm{N}$ and $\mathrm{K}$. This is in accordance with Popat Kadu et al. (2012)[27] on kharif cotton in Maharastra.

The per cent contribution from fertilizer nutrients (Cf) towards the total uptake by cotton was 52.01, 49.89 and 73.35 per cent, respectively for $\mathrm{N}, \mathrm{P}_{2} \mathrm{O}_{5}$ and $\mathrm{K}_{2} \mathrm{O}$ and followed the order of $\mathrm{K}_{2} \mathrm{O}>\mathrm{N}>\mathrm{P}_{2} \mathrm{O}_{5}$. The estimated per cent contribution of nutrients from fertilizers (Cf) to total uptake clearly revealed the fact that the magnitude of contribution by fertilizer $\mathrm{K}_{2} \mathrm{O}$ was 1.47 times higher than $\mathrm{P}_{2} \mathrm{O}_{5}$ and 1.41 times as that of $\mathrm{N}$. The contribution from fertilizers was higher than from the soil for all the three nutrients. The findings are closely accorded with those reported by Anon (2012)[28] for transgenic cotton BRAHMA on black calcareous soil. The contribution of nutrients towards the growth of the crop was higher from fertilizers than that of soil for all the three nutrients $\left(\mathrm{N}, \mathrm{P}_{2} \mathrm{O}_{5}\right.$ and $\left.\mathrm{K}_{2} \mathrm{O}\right)$.

\subsubsection{Contribution of nutrients from FYM}

With a view to evaluate the extent to which the fertilizer requirements of cotton can be reduced under IPNS, the contribution of nutrients from FYM is to be quantified. Accordingly, the fourth basic parameter for the targeted yield model, the per cent contribution of $\mathrm{N}, \mathrm{P}_{2} \mathrm{O}_{5}$ and $\mathrm{K}_{2} \mathrm{O}$ from FYM was computed. The estimated per cent contribution of $\mathrm{N}, \mathrm{P}_{2} \mathrm{O}_{5}$ and $\mathrm{K}_{2} \mathrm{O}$ from FYM (Cfym) were 38.19, 16.43 and 40.35 respectively for cotton which indicated that relatively higher contribution was recorded for $\mathrm{K}_{2} \mathrm{O}$ followed by $\mathrm{N}$ and $\mathrm{P}_{2} \mathrm{O}_{5}$. The present findings corroborated with the findings of Santhi et al. (2002)[29] and Saranya et al. (2012)[30] and the response yardstick recorded was $5.13 \mathrm{~kg} \mathrm{~kg}^{-1}$.

\subsection{Fertilizer prescription equations for transgenic cotton under drip fertigation}

Soil test based fertilizer prescription equations for desired yield target of cotton were formulated using the basic parameters and are furnished below:

\begin{tabular}{llll}
\multicolumn{2}{c}{ STCR-NPK alone } & \multicolumn{2}{c}{ STCR-IPNS (NPK + FYM) } \\
$\mathrm{FN}=$ & $8.51 \mathrm{~T}-0.47 \mathrm{SN}$ & $\mathrm{FN}=$ & $8.51 \mathrm{~T}-0.47 \mathrm{SN}-0.73 \mathrm{ON}$ \\
$\mathrm{F}_{2} \mathrm{O}_{5}=$ & $4.41 \mathrm{~T}-2.25 \mathrm{SP}$ & $\mathrm{F} \mathrm{P}_{2} \mathrm{O}_{5}=$ & $4.41 \mathrm{~T}-2.25 \mathrm{SP}-0.75 \mathrm{OP}$ \\
$\mathrm{FK}_{2} \mathrm{O}=$ & $6.59 \mathrm{~T}-0.18 \mathrm{SK}$ & $\mathrm{FK}_{2} \mathrm{O}=$ & $6.59 \mathrm{~T}-0.18 \mathrm{SK}-0.66 \mathrm{OK}$
\end{tabular}

where, $\mathrm{FN}, \mathrm{FP}_{2} \mathrm{O}_{5}$ and $\mathrm{FK}_{2} \mathrm{O}$ are fertilizer $\mathrm{N}, \mathrm{P}_{2} \mathrm{O}_{5}$ and $\mathrm{K}_{2} \mathrm{O}$ in $\mathrm{kg} \mathrm{ha}^{-1}$, respectively; $\mathrm{T}$ is the yield target in $\mathrm{q} \mathrm{ha}^{-1}$; $\mathrm{SN}$, SP and SK respectively are alkaline $\mathrm{KMnO}_{4}-\mathrm{N}$, Olsen-P and $\mathrm{NH}_{4} \mathrm{OAc}-\mathrm{K}$ in kg ha ${ }^{-1}$ and $\mathrm{ON}$, OP and $\mathrm{OK}$ are the quantities of $\mathrm{N}, \mathrm{P}$ and $\mathrm{K}$ supplied through FYM in $\mathrm{kg} \mathrm{ha}^{-1}$.

Fertilizer response is denoted by the functional relationship between increase in crop yield and added fertilizers. It can be expressed graphically or algebraically by an equation. Milap Chand et al., (2006)[31] reported the superiority of the target yield concept over other practices for different crops as it gave higher yields, net benefit and optimal economic returns. The yield targets were achieved within reasonable limits when the fertilizer was applied on soil test basis in majority of the crops thus establishing the utility of the prescription equations for recommending soil test based fertilizer application to the farmers. With this background, in the present investigation, soil test based fertilizer prescription equations for desired yield target of cotton was developed using the basic parameters obtained. The data clearly revealed the fact that the fertilizer $\mathrm{N}_{2} \mathrm{P}_{2} \mathrm{O}_{5}$ and $\mathrm{K}_{2} \mathrm{O}$ requirements decreased with increase in soil test values and increased with increase in yield targets.

Realizing the superiority of the targeted yield approach, Santhi et al. (2012) [32]documented in a handbook the soil test and yield target based fertilizer prescriptions under IPNS for 25 crops comprising cereals, millets, pulses, oilseeds, sugarcane, cotton, vegetables, spices and medicinal crops on 14 soil series for Tamil Nadu.

\subsection{Fertilizer prescription under IPNS for desired yield target of transgenic cotton}

A ready reckoner table was prepared using these equations for a range of soil test values and for a yield target of $30 \mathrm{q} \mathrm{ha}^{-1}$ for cotton (Table 5). For achieving an yield target of $30 \mathrm{q} \mathrm{ha}^{-1}$ of seed cotton with a soil test value of 280,20 and $500 \mathrm{~kg} \mathrm{ha}^{-1}$ of $\quad \mathrm{KMnO}_{4}-\mathrm{N}$, Olsen-P and $\mathrm{NH}_{4} \mathrm{OAc}-\mathrm{K}$, the fertilizer $\mathrm{N}, \mathrm{P}_{2} \mathrm{O}_{5}$ and $\mathrm{K}_{2} \mathrm{O}$ doses required were 124, 87 and $108 \mathrm{~kg} \mathrm{ha}^{-1}$, respectively under NPK alone and 84, 67 and $74 \mathrm{~kg} \mathrm{ha}^{-1}$ under IPNS 
(NPK + FYM @ 12.5 t ha $^{-1}$ with 32, 0.64, 0.31 and 0.61 per cent of moisture, N, P and K respectively). Similarly for the target of $35 \mathrm{q} \mathrm{ha}^{-1}$, the respective values were 166, 109 and $141 \mathrm{~kg} \mathrm{ha}^{-1}$ under NPK alone and 126, 89 and 107 under IPNS. Under IPNS, the fertilizer savings were 40, 20 and $34 \mathrm{~kg} \mathrm{ha}^{-1}$ respectively when FYM was applied @ $12.5 \mathrm{t} \mathrm{ha}^{-1}$ along with NPK fertilizers.

In the present investigation, there was a marked response to the application of NPK fertilizers, the magnitude of response was higher under IPNS as compared to NPK alone. The per cent reduction in NPK fertilizers under IPNS also increased with increasing soil fertility levels with reference to NPK and decreased with increase in yield targets. These could be achieved by integrated use of FYM with NPK fertilizers. The role of FYM is multidimensional ranging from building up of organic matter, maintaining favourable soil physical properties and balanced supply of nutrients. In the present investigation also, these factors might have contributed for the yield enhancement in cotton when NPK fertilizers are coupled with FYM. Similar trend of results were reported by Anon (2012) in transgenic cotton.

\subsection{Test verification trial}

In order to validate the fertilizer prescription equations developed for transgenic cotton on Periyanaickenpalayam soil series (Inceptisol), test verification trial was conducted at TNAU farm, Coimbatore on the same soil series. There were nine treatments viz., blanket recommendation, STCR-NPK alone for 3.0, 3.5 and $4.0 \mathrm{t} \mathrm{ha}^{-1}$ yield targets, STCR-IPNS for 3.0, 3.5 and $4.0 \mathrm{t} \mathrm{ha}^{-1}$ yield targets, farmer's practice and absolute control. The treatment details and results are furnished in Table 6.

\subsubsection{Seed cotton yield and achievement}

The results of the test verification trial revealed that the seed cotton yield ranged from $1.81 \mathrm{t} \mathrm{ha}^{-1}$ in control to $4.14 \mathrm{t} \mathrm{ha}^{-1}$ in STCR-IPNS $4.0 \mathrm{t} \mathrm{ha}^{-1}$. Irrespective of the yield targets, the yield recorded in the STCRIPNS treatments were higher when compared to their corresponding STCR-NPK alone treatments. The seed cotton yield under general recommendation of fertilizers and farmer's practice lagged behind the yield obtained at 3.0, 3.5 and $4.0 \mathrm{t} \mathrm{ha}^{-1}$ fixed targets. The results of the test verification trial on transgenic cotton clearly indicated that the per cent achievement was within \pm 10 per cent variation (90 to $110 \%)$ at all yield target levels proving the validity of the fertilizer prescription equations. According to Velayutham et al. (1984)[33], if the targeted yield was achieved within \pm 10 per cent variation, then the equations are found to be valid. The highest achievement of the yield targets was recorded with STCR-IPNS target of $4.00 \mathrm{t} \mathrm{ha}^{-1}(105.0 \%)$ followed by STCR-IPNS target of $3.5 \mathrm{t} \mathrm{ha}^{-1}$ treatments $(104.3 \%)$. The yield targeting with IPNS recorded relatively higher percent achievement than that aimed under their respective NPK alone treatments. It is evident from the data that lower yield targets were better achieved than the higher one in both the crops. This might be due to the better use efficiency of applied NPK fertilizers at low yield target levels (Santhi et al., 2002 and Bera et al., 2006) (Table 6).

\subsubsection{Response ratio $(R R)$}

The RR recorded for various treatments ranged from $3.07 \mathrm{~kg} \mathrm{~kg}^{-1}$ in farmer's practice to $4.31 \mathrm{~kg} \mathrm{~kg}^{-1}$ in STCR-IPNS- $4.0 \mathrm{t} \mathrm{ha}^{-1}$. Among the STCR treatments, IPNS recorded relatively higher RR than NPK alone treatments (Table 6). Relatively higher RR recorded under STCR-IPNS treatments when compared to blanket and farmer's practice might be due to balanced supply of nutrients from fertilizer, efficient utilization of applied fertilizer nutrients in the presence of organic sources and the synergistic effect of the conjoint addition of various sources of nutrients. Similar trend of superiority of STCR-IPNS over farmer's practice was reported by Coumaravel (2012)[34] for maize-tomato sequence. 


\section{Figures And Tables}

Fig.1. Layout plan of STCR -IPNS experiment with transgenic cotton under drip fertigation

\begin{tabular}{|c|c|c|c|c|c|c|c|}
\hline & \multicolumn{2}{|c|}{ STRIP I } & \multicolumn{2}{|c|}{ STRIP II } & \multicolumn{2}{|c|}{ STRIP III } & \\
\hline \multirow{12}{*}{$\stackrel{5}{0}$} & NOPOKO & N2P3K2 & NOPOKO & $\mathrm{N}_{3} \mathrm{P}_{2} \mathrm{~K} 3$ & NOPOKO & N2P2K1 & \multirow{4}{*}{$\begin{array}{c}\text { NPK alone } \\
\text { B I }\end{array}$} \\
\hline & N2P2Ko & N2P1K1 & N3P2K1 & $\mathrm{N} 2 \mathrm{P} 2 \mathrm{~K} 3$ & N3P3K1 & NIPIKI & \\
\hline & N3P1K & N1P1K2 & N2POK B & N1P2K1 & NOP $2 K 2$ & N2P3K3 & \\
\hline & N1P2K2 & N3P3K2 & $\mathrm{N} 2 \mathrm{P} 2 \mathrm{~K} 2$ & N3P3K3 & N3P2K2 & N2P1K2 & \\
\hline & NOPOKO & N3P2K3 & NOPOKO & N2P2K1 & NOPOKO & N2P3K2 & \multirow{2}{*}{$\begin{array}{l}\text { NPK+ } \\
6.25 \mathrm{tha}^{-1} \\
\text { FYM }\end{array}$} \\
\hline & N3P2K1 & N2P2K3 & N3P3K1 & NIPIKI & N2P2K0 & N2P1K1 & \\
\hline & N2POK. & N1P2KI & NOP2K. & N2P3K3 & N3P1K & N1P1K2 & \multirow{2}{*}{ B II } \\
\hline & N2P2K2 & N3P3K3 & N3P2K2 & N2P1K2 & N1P2K2 & N3P3K2 & \\
\hline & NOPOKO & N2P2K1 & NOPOKO & N2P3K2 & NOPOKO & N3P2K3 & \multirow{3}{*}{$\begin{array}{c}\text { NPK+ } \\
12.5 \text { tha } \\
\text { FYM }\end{array}$} \\
\hline & N3P3K1 & N1P1K1 & N2P2KO & N2P1K1 & N3P2K1 & N2P2K3 & \\
\hline & NOP2K C & N2P3K3 & N3P1K A & N1P1K2 & N2P0K & N1P2K1 & \\
\hline & N3P2K2 & N2P1K2 & N1P2K2 & N3P3K2 & $\mathrm{N} 2 \mathrm{P} 2 \mathrm{~K} 2$ & N3P3K3 & \\
\hline \multicolumn{8}{|c|}{ Treatment structure } \\
\hline & $\mathbf{N}_{0} \mathbf{P}_{\circ} \mathrm{K}_{0}$ & \multicolumn{2}{|c|}{ 5. $\mathbf{N}_{1} \mathbf{P}_{1} \mathbf{K}_{1}$} & \multicolumn{2}{|c|}{ 9. $\mathbf{N}_{2} P_{1} K_{1}$} & \multicolumn{2}{|c|}{ 18. $\mathrm{N}_{3} \mathrm{P}_{1} \mathrm{~K}_{1}$} \\
\hline & $\mathrm{N}_{0} \mathrm{P}_{0} \mathrm{~K}_{\mathrm{0}}$ & \multirow{2}{*}{\multicolumn{2}{|c|}{$\begin{array}{l}\text { 6. } \mathrm{N}_{1} \mathbf{P}_{1} \mathbf{K}_{2} \\
\text { 7. } \mathrm{N}_{1} \mathbf{P}_{2} \mathbf{K}_{1}\end{array}$}} & \multirow{2}{*}{\multicolumn{2}{|c|}{$\begin{array}{l}\text { 10. } \mathrm{N}_{2} \mathrm{P}_{0} \mathrm{~K}_{2} \\
11 . \mathrm{N}_{2} \mathrm{P}_{1} \mathrm{~K}_{2}\end{array}$}} & \multirow{2}{*}{\multicolumn{2}{|c|}{$\frac{19 . N_{3} P_{2} K_{1}}{20 . N_{3} P_{2} K_{2}}$}} \\
\hline & $\mathrm{N}_{\mathrm{O}} \mathrm{P}_{\mathrm{O}} \mathrm{K}_{\mathrm{o}}$ & & & & & & \\
\hline \multirow{2}{*}{\multicolumn{2}{|c|}{ 4. $\mathrm{N}_{0} \mathrm{P}_{2} \mathrm{~K}_{2}$}} & \multicolumn{2}{|c|}{ 8. $\mathrm{N}_{1} \mathrm{P}_{2} \mathrm{~K}_{2}$} & $12 . \mathrm{N}$ & $\mathrm{P}_{2} \mathrm{~K}_{0}$ & $21 . \mathrm{N}_{2}$ & ${ }_{3} \mathrm{~K}_{1}$ \\
\hline & & & & $13 . \mathrm{N}$ & $\mathrm{P}_{2} \mathrm{~K}_{1}$ & 22. $\mathrm{N}_{3}$ & ${ }_{3} \mathrm{~K}_{2}$ \\
\hline & & & & $14 . \mathrm{N}$ & $\mathrm{P}_{2} \mathrm{~K}_{2}$ & 23. $\mathrm{N}_{3}$ & ${ }_{2} \mathrm{~K}_{3}$ \\
\hline & & & & $15 . \mathrm{N}$ & $\mathrm{P}_{2} \mathrm{~K}_{3}$ & 24. $\mathrm{N}_{3}$ & ${ }_{3} \mathrm{~K}_{3}$ \\
\hline & & & & $16 . \mathrm{N}$ & $\mathrm{P}_{3} \mathrm{~K}_{2}$ & & \\
\hline & & & & $17 . \mathrm{N}$ & $\mathrm{P}_{3} \mathrm{~K}_{3}$ & & \\
\hline
\end{tabular}

Table 1 Details of crops and important cultural operations

\begin{tabular}{|c|l|c|c|c|}
\hline $\begin{array}{c}\text { Sl. } \\
\text { No. }\end{array}$ & \multicolumn{1}{|c|}{$\begin{array}{c}\text { Details of cultural } \\
\text { operations }\end{array}$} & $\begin{array}{c}\text { Gradient experiment Fodder } \\
\text { maize }(\text { CO 1) }\end{array}$ & $\begin{array}{c}\text { Test crop experiment } \\
\text { Cotton (RCH 530 BGII) }\end{array}$ & $\begin{array}{c}\text { Test verification trial } \\
\text { Cotton (RCH 530 BGII) }\end{array}$ \\
\hline 1 & Season & June-August & October- April & August - February \\
2 & Strip/Plot size $\left(\mathrm{m}^{2}\right)$ & 705 & 27 & 58 \\
3 & Date of sowing & 24.06 .2011 & 01.10 .2011 & 31.08 .2012 \\
4 & Spacing $(\mathrm{cm})$ & $30 \times 15$ & $120 \times 90$ & $120 \times 90$ \\
5 & Date of harvest & 18.8 .2011 & $07.03 .12-28.04 .12$ & $8.01 .13-26.02 .13$ \\
\hline
\end{tabular}

Table 2 Pre-sowing soil available NPK, seed cotton yield and NPK uptake by cotton $\left(\mathrm{kg} \mathrm{ha}^{-1}\right)$

\begin{tabular}{|c|c|c|c|c|c|c|}
\hline \multirow{2}{*}{$\begin{array}{r}\text { Parameters } \\
\left.\mathrm{ha}^{-1}\right)\end{array}$} & \multicolumn{2}{|c|}{ Strip I } & \multicolumn{2}{|c|}{ Strip II } & \multicolumn{2}{|c|}{ Strip III } \\
\hline & Range & Mean & Range & Mean & Range & Mean \\
\hline $\mathrm{KMnO}_{4}-\mathrm{N}$ & $207-216$ & 213 & $232-241$ & 238 & $252-260$ & 255 \\
\hline Olsen-P & $15-18$ & 16.4 & $28-33$ & 30.4 & $36-42$ & 38.0 \\
\hline $\mathrm{NH}_{4} \mathrm{OAc}-\mathrm{K}$ & $550-560$ & 554 & $584-594$ & 589 & $606-613$ & 609 \\
\hline Seed cotton yield & $1082-2618$ & 2146 & $1275-3405$ & 2691 & $1406-3401$ & 2803 \\
\hline $\mathrm{N}$ uptake & $43.2-117.1$ & 94.0 & $57.8-152.9$ & 118.0 & $63.8-152.6$ & 124.5 \\
\hline P uptake & $8.7-24.9$ & 19.5 & $13.1-47.7$ & 27.6 & $13.0-46.6$ & 28.4 \\
\hline K uptake & $52.2-103.4$ & 84.2 & $62.2-140.2$ & 109.9 & $69.9-139.7$ & 114.8 \\
\hline
\end{tabular}

Table 3 Response of transgenic cotton to different levels of fertilizer nutrients

\begin{tabular}{|c|c|c|c|c|c|c|c|c|c|}
\hline & \multicolumn{3}{|c|}{ Nitrogen $(\mathrm{N})$} & \multicolumn{3}{c|}{ Phosphorus $\left(\mathrm{P}_{2} \mathrm{O}_{5}\right)$} & \multicolumn{3}{c|}{ Potassium $\left(\mathrm{K}_{2} \mathrm{O}\right)$} \\
\cline { 2 - 10 } S.No. & $\begin{array}{c}\text { Level } \\
\left(\mathrm{kg} \mathrm{ha}^{-1}\right)\end{array}$ & $\begin{array}{c}\text { Response } \\
(\mathrm{kg})\end{array}$ & $\begin{array}{c}\text { Response } \\
\text { Ratio } \\
\left(\mathrm{kg} \mathrm{kg}^{-1}\right)\end{array}$ & $\begin{array}{c}\text { Level } \\
\left(\mathrm{kg} \mathrm{ha}^{-1}\right)\end{array}$ & $\begin{array}{c}\text { Response } \\
(\mathrm{kg})\end{array}$ & $\begin{array}{c}\text { Response } \\
\text { Ratio } \\
\left(\mathrm{kg} \mathrm{kg}^{-1}\right)\end{array}$ & $\begin{array}{c}\text { Level } \\
\left(\mathrm{kg} \mathrm{ha}^{-1}\right)\end{array}$ & $\begin{array}{c}\text { Response } \\
\left(\mathrm{kg}^{2}\right)\end{array}$ & $\begin{array}{c}\text { Response } \\
\text { Ratio } \\
\left(\mathrm{kg} \mathrm{kg}^{-1}\right)\end{array}$ \\
\hline 1. & 60 & 252 & 4.20 & 30 & 92 & 3.07 & 40 & 97 & 2.43 \\
2. & 120 & 572 & 4.77 & 60 & 271 & 4.52 & 80 & 214 & 2.68 \\
3. & 180 & 956 & 5.30 & 90 & 413 & 4.60 & 120 & 354 & 2.95 \\
\hline
\end{tabular}

Table 4. Nutrient requirement, contribution of nutrients from soil, fertilizer and FYM $(\%)$ for cotton

\begin{tabular}{|c|c|c|c|}
\hline \multirow{2}{*}{ Parameters } & \multicolumn{3}{|c|}{ Basic data } \\
\cline { 2 - 4 } & $\mathrm{N}$ & $\mathrm{P}_{2} \mathrm{O}_{5}$ & $\mathrm{~K}_{2} \mathrm{O}$ \\
\hline Nutrient requirement $\left(\mathrm{kg} \mathrm{q}^{-1}\right)$ & 4.43 & 2.20 & 4.83 \\
Per cent contribution from soil (Cs) & 24.65 & 48.95 & 11.06 \\
Per cent contribution from fertilizers (Cf) & 52.01 & 49.89 & 73.35 \\
Per cent contribution from FYM (Cfym) & 38.19 & 16.43 & 40.35 \\
\hline
\end{tabular}


Soil Test Based Fertilizer Prescriptions Through Inductive Cum Targeted Yield Model For

Table 5. Soil test based fertilizer prescription for yield target of 30,35 and $40 \mathrm{q} \mathrm{ha}^{-1}$ of cotton $\left(\mathrm{kg} \mathrm{ha}^{-1}\right)$

\begin{tabular}{|c|c|c|c|c|c|c|c|c|c|}
\hline \multirow{2}{*}{$\begin{array}{c}\text { Soil Test } \\
\text { Values (kg } \\
\left.\text { ha }^{-1}\right)\end{array}$} & \multicolumn{2}{|c|}{$\begin{array}{l}\text { Fertilizer-N } \\
\left(\mathrm{kg} \mathrm{ha}^{-1}\right)\end{array}$} & \multirow{2}{*}{$\begin{array}{c}\text { Per cent } \\
\text { reduction } \\
\text { over NPK }\end{array}$} & \multicolumn{2}{|c|}{$\begin{array}{c}\text { Fertilizer-P } \\
\left.\mathrm{ha}^{-1}\right)\end{array} \quad(\mathrm{kg}$} & \multirow{2}{*}{$\begin{array}{c}\text { Per cent } \\
\text { reduction } \\
\text { over NPK }\end{array}$} & \multicolumn{2}{|c|}{$\underset{\substack{\left.\text { Fertilizer-K } \\
\mathrm{ha}^{-1}\right)} \quad(\mathrm{kg}}{ }$} & \multirow{2}{*}{$\begin{array}{c}\text { Per cent } \\
\text { reduction } \\
\text { over NPK }\end{array}$} \\
\hline & $\begin{array}{l}\text { NPK } \\
\text { alone }\end{array}$ & $\begin{array}{l}\text { NPK+ } \\
\text { FYM }\end{array}$ & & $\begin{array}{l}\text { NPK } \\
\text { alone }\end{array}$ & $\begin{array}{l}\text { NPK+ } \\
\text { FYM }\end{array}$ & & $\begin{array}{l}\text { NPK } \\
\text { alone }\end{array}$ & $\begin{array}{l}\text { NPK+ } \\
\text { FYM }\end{array}$ & \\
\hline $\mathrm{KMnO}_{4}-\mathrm{N}$ & \multicolumn{3}{|c|}{$30 \mathrm{q} \mathrm{ha}^{-1}$} & \multicolumn{3}{|c|}{$35 \mathrm{q} \mathrm{ha}^{-1}$} & \multicolumn{3}{|c|}{$40 \mathrm{q} \mathrm{ha}^{-1}$} \\
\hline 160 & 180 & 140 & 22.2 & 223 & 183 & 18.0 & 265 & 225 & 15.1 \\
\hline 180 & 171 & 131 & 23.4 & 213 & 173 & 18.8 & 256 & 216 & 15.6 \\
\hline 200 & 161 & 121 & 24.8 & 204 & 164 & 19.6 & 246 & 206 & 16.2 \\
\hline 220 & 152 & 112 & 26.3 & 194 & 154 & 20.6 & 237 & 197 & 16.9 \\
\hline 240 & 143 & 103 & 28.1 & 185 & 145 & 21.6 & 228 & 188 & 17.6 \\
\hline 260 & 133 & 93 & 30.1 & 176 & 136 & 22.8 & 218 & 178 & 18.3 \\
\hline 280 & 124 & 84 & 32.3 & 166 & 126 & 24.1 & 209 & 169 & 19.2 \\
\hline Olsen-P & \multicolumn{3}{|c|}{$30 \mathrm{q} \mathrm{ha}^{-1}$} & \multicolumn{3}{|c|}{$35 \mathrm{q} \mathrm{ha}^{-1}$} & \multicolumn{3}{|c|}{$40 \mathrm{q} \mathrm{ha}^{-1}$} \\
\hline 10 & 110 & 90 & 18.2 & 132 & 112 & 15.2 & 154 & 134 & 13.0 \\
\hline 12 & 105 & 85 & 19.0 & 127 & 107 & 15.7 & 149 & 129 & 13.4 \\
\hline 14 & 101 & 81 & 19.8 & 123 & 103 & 16.3 & 145 & 125 & 13.8 \\
\hline 16 & 96 & 76 & 20.8 & 118 & 98 & 16.9 & 140 & 120 & 14.2 \\
\hline 18 & 92 & 72 & 21.8 & 114 & 94 & 17.6 & 136 & 116 & 14.7 \\
\hline 20 & 87 & 67 & 22.9 & 109 & 89 & 18.3 & 131 & 111 & 15.2 \\
\hline 22 & 83 & 63 & 24.2 & 105 & 85 & 19.1 & 127 & 107 & 15.8 \\
\hline $\mathrm{NH}_{4} \mathrm{OAc}-\mathrm{K}$ & \multicolumn{3}{|c|}{$30 \mathrm{qha}^{-1}$} & \multicolumn{3}{|c|}{$35 \mathrm{qha}^{-1}$} & \multicolumn{3}{|c|}{$40 \mathrm{q} \mathrm{ha}^{-1}$} \\
\hline 300 & 144 & 110 & 23.7 & 177 & 143 & 19.2 & 210 & 176 & 16.2 \\
\hline 350 & 135 & 101 & 25.2 & 168 & 134 & 20.3 & 201 & 167 & 16.9 \\
\hline 400 & 126 & 92 & 27.0 & 159 & 125 & 21.4 & 192 & 158 & 17.7 \\
\hline 450 & 117 & 83 & 29.1 & 150 & 116 & 22.7 & 183 & 149 & 18.6 \\
\hline 500 & 108 & 74 & 31.6 & 141 & 107 & 24.2 & 174 & 140 & 19.6 \\
\hline 550 & 99 & 65 & 34.4 & 132 & 98 & 25.8 & 165 & 131 & 20.7 \\
\hline 600 & 90 & 56 & 37.9 & 123 & 89 & 27.7 & 156 & 122 & 21.9 \\
\hline
\end{tabular}

Table 6. Results of the test verification trial on cotton

\begin{tabular}{|c|c|c|c|c|c|c|c|c|}
\hline \multirow{2}{*}{$\begin{array}{l}\text { Sl. } \\
\text { No }\end{array}$} & \multirow{2}{*}{ Treatments } & \multicolumn{3}{|c|}{$\begin{array}{c}\text { Fertilizer doses } \\
\left(\mathrm{kg} \mathrm{ha}^{-1}\right)\end{array}$} & \multirow{2}{*}{$\begin{array}{c}\text { Yield } \\
\left(\mathrm{t} \mathrm{ha}^{-1}\right)\end{array}$} & \multirow{2}{*}{$\begin{array}{c}\text { Per cent } \\
\text { achievement }\end{array}$} & \multirow{2}{*}{$\begin{array}{c}\mathrm{RR} \\
\left(\mathrm{kg} \mathrm{kg}^{-1}\right)\end{array}$} & \multirow[t]{2}{*}{$\mathrm{BCP}$} \\
\hline & & $\mathrm{N}$ & $\mathrm{P}_{2} \mathrm{O}_{5}$ & $\mathrm{~K}_{2} \mathrm{O}$ & & & & \\
\hline T1 & Blanket & 120 & 60 & 60 & 2.55 & - & 3.08 & 1.7 \\
\hline $\mathrm{T} 2$ & STCR-NPK alone-3.0 tha ${ }^{-1}$ & 166 & 80 & 99 & 3.02 & 100.7 & 3.51 & 2.0 \\
\hline T3 & STCR-NPK alone-3.5 $\mathrm{tha}^{-1}$ & 209 & 102 & 132 & 3.51 & 100.3 & 3.84 & 2.2 \\
\hline $\mathrm{T} 4$ & STCR-NPK alone- $4.0 \mathrm{t} \mathrm{ha}^{-1}$ & 251 & 124 & 165 & 3.99 & 99.8 & 4.04 & 2.4 \\
\hline T5 & STCR -IPNS- $3.0 \mathrm{t} \mathrm{ha}^{-1}$ & 121 & 58 & 59 & 3.15 & 105.0 & 3.88 & 2.0 \\
\hline T6 & STCR -IPNS- $3.5 \mathrm{tha}^{-1}$ & 164 & 80 & 92 & 3.65 & 104.3 & 4.15 & 2.3 \\
\hline $\mathrm{T} 7$ & STCR -IPNS- $4.0 \mathrm{t} \mathrm{ha}^{-1}$ & 206 & 102 & 125 & 4.14 & 103.5 & 4.31 & 2.5 \\
\hline $\mathrm{T} 8$ & Farmer's Practice & 110 & 55 & 60 & 2.50 & - & 3.07 & 1.7 \\
\hline $\mathrm{T} 9$ & Control & - & - & - & 1.81 & - & & 1.4 \\
\hline \multicolumn{5}{|c|}{ SEd ( $( \pm)$} & 0.09 & & & \\
\hline & \multicolumn{4}{|c|}{ C.D (0.05) } & 0.18 & & & \\
\hline
\end{tabular}

\section{Conclusion}

To conclude, soil test based IPNS for desired yield targets of transgenic cotton was developed and validated on Vertic Ustropept of Tamil Nadu under drip fertigation in the present investigation taking into account the nutrient requirement and contribution of $\mathrm{N}, \mathrm{P}$ and $\mathrm{K}$ from various nutrient sources (soil, fertilizer and FYM). This envisages a balanced nutrient supply to transgenic cotton which is site specific and can play a major component of precision agriculture. The specific yield equation based on soil health will not only ensure sustainable crop production but will also steer the farmers towards economic use of costly fertilizer inputs. The fertilizer prescription equations developed using this model can be applied to Inceptisols of all tropical regions by substituting the soil nutrient status of the particular field. Moreover, the methodology adopted in the present investigation viz., the prescription procedure outlined by Truog (1960) and modified by Ramamoorthy et al. (1967) as "Inductive cum Targeted yield model" can very well be used to derive fertilizer prescription equations for any field or horticultural crop (except perennial crops) on any soil series. 


\section{Acknowledgements}

The authors gratefully acknowledge the Indian Council of Agricultural Research, New Delhi and Indian Institute of Soil Science, Bhopal and Tamil Nadu Agricultural University, Coimbatore for funding and implementing the All India Coordinated Research Project for Investigations on Soil Test Crop Response Correlation (AICRP-STCR) at Tamil Nadu Agricultural University, Coimbatore.

\section{References}

[1] United States Department of Agriculture, Economic Research Service. 2011. <http://www.ers.usda.gov/Briefing/Cotton/> (accessed 18.07.11).

[2] E.F. Bazen, J.A. Larson, R.K. Roberts, Economics of fertility management in cotton production in the United States, Dynam. Soil Dynam. Plant 1, 2007, 95-104.

[3] A.S.Tayade, M.V.Dhoble, Effect of transgenic cotton hybrid, nutrient and pest management on seed cotton yield, nutrient uptake and status of available nutrient in soil, Indian J. Fert., 6(8) 2010, 34- 40

[4] A.L. Bhandari, J.K. Ladha, H. Pathak, A.T. Padre, D. Dawae, R.K. Gupta, Yield and soil nutrient changes in a long-term ricewheat rotation in India, Soil Sci. Soc. Am. , 58, 2002, 185-193.

[5] J.K. Ladha, D. Dawe, H. Pathak, A.T. Padre, R.L. Yadav, B. Singh, Y. Singh, P. Singh, A.L. Kundu, R. Sakal, N. Ram, A.P. Regni, S.K. Gami, A.L. Bhandari, R. Amin, C.R. Yadav, E.M. Bhattarai, S. Das, H.P. Aggarwal, R.K. Gupta, P.R. Hobbs, How extensive are yield declines in long-term rice-wheat experiments in Asia? Field Crops Res., 81, 2003, 159-180.

[6] M.C., Manna, A., Swarup, R.H., Wanjari, H.N., Ravankar, B., Mishra, M.N., Saha, Y.V., Singh, D.K.,Sahi, P.A.Sarap, Long-term effect of fertilizer and manure application on soil organic carbon storage, soil quality and yield sustainability under sub-humid and semi-arid tropical India, Field Crops Res., 93, 2005, 264-280.

[7] A. Dobermann, C. Witt, S. Abdulrachman, H.C. Gines, R. Nagarajan, T.T. Son, P.S. Tan, G.H.Wang, N.V. Chien, V.T.K. Thoa, Soil fertility and indigenous nutrient supply in irrigated rice domains of Asia, Agron. J., 95, 2003, 913-923.

[8] E.Truog, Fifty years of soil testing, Proc. Trans $7^{\text {th }}$ Intl. Congr. Soil Sci. Vol. III Commission IV paper No.7: 1960, 46-53

[9] J. Liebig Von, Die Grundsatze der Agric. Braunshweing, Quoted by G.R. Maruthi Sankar. Application of statistical model building and optimization techniques in fertilizer use research, 1855, in L.L. Somani, K.P.R. Vittal and B. Venkateswarlu, (Ed.), Dry land Agriculture - State of Art of Research in India (Scientific Publishers, Jodhpur, 1992), 653-670.

[10] M. Velayutham, Fertilizer recommendation based on targeted yield concept, problems and prospects, Fert. News, 24(9), 1979, 1220 .

[11] B. Ramamoorthy, M. Velayutham, Soil Test Crop Response Correlation work in India, World soil resources report No. 41, FAO, Rome, 1971, 96-105.

[12] B. Ramamoorthy, M. Velayutham, Soil fertility and fertilizer use research in India, Indian Fmg., 21(6), 1972, 80-84.

[13] B., Ramamoorthy, M. Velayutham, Soil testing for high fertiliser efficiency. Indian Fmg., 24 (2), 1974, 82-84.

[14] C.A. Black, Soil Fertility Evaluation and Control (Lewis Publishers, Boca Raton, 1993), 171-175.

[15] A. Dobermann, P.F. White, Strategies for nutrient management in irrigated and rain fed lowland rice systems, Nutrient Cycling Agroecosyst, 53(1), 1998, 1-18.

[16] C. Witt, A. Dobermann, S. Abdulrachman, H.C. Gines, G.H. Wang, R. Nagarajan, S. Satawathananont, T.T. Son, P.S. Tan, L.V. Tiem, Internal nutrient efficiencies of irrigated lowland rice in tropical and subtropical Asia. Field Crops Res., 63(2), 1999, 113138. [Doi: 10.1016/S0378-4290(99)00031-3]

[17] H.L. Sakarvadia, K.B. Polara, R.L. Davaria, K.B. Parmar, and N.B. Babariya, Soil test based fertilizer recommendation for targeted yields of garlic crop, An Asian J. Soil Sci., 7(2), 2012, 378382.

[18] M.K. Khosa, B.S. Sekhon, M.S. Ravi, D.S. Benipal, D.K. Benbi, Performance of target yield based fertilizer prescription equations in rice-wheat cropping system in Punjab, Indian J. Fert., 8(2), 2012, 14-18

[19] R. Bera, A. Seal, P. Bhattacharyya, T.H. Das, D. Sarkar, K. Kangjoo, Targeted yield concept and a framework of fertilizer recommendation in irrigated rice domains of subtropical India, J Zhejiang Univ Sci., 7(12), 2006, 963-968.

[20] B. Ramamoorthy, R.K. Narasimham, R.S. Dinesh, Fertilizer application for specific yield targets on Sonora 64 (wheat), Indian Fmg 17, 1967, 43-45.

[21] B.V. Subbiah, G.L. Asija, A rapid procedure for the estimation of available nitrogen in soils, Curr Sci 25, 1956, 259-260

[22] S.R. Olsen, C.V. Cole, F.S. Watanabe, L. Dean, Estimation of available phosphorus in soils by extraction with sodium bicarbonate. U.S.D.A. Circ. 939, U.S. Govt. Printing Office, Washington, DC, 1954.

[23] S. Stanford, L. English, Use of flame photometer in rapid soil tests of K and Ca. Agron. J. 41, 1949, 446

[24] E.C. Humphries, Mineral components and ash analysis, in (Ed.), Modern methods of plant analysis, (Springer - Verlag, Berlin 1: 1956) 468-562.

[25] M.L. Jackson, Soil chemical analysis (Prentice Hall of India Private Ltd., New Delhi, 1973).

[26] O. Gormus, C. Yucel, Different planting dates and potassium fertility effects on cotton yield and fibre properties in the Cukurova region, Turkey, Field crops Res. 78, 2002, 141-149.

[27] Popat Kadu, V.K. Kharche, A.D. Kadlog, Fertiliser and manure prescription equations for different crops grown in various districts of Maharashtra, in A. Muralidharudu, A. Subba Rao and K. Sammi Reddy, (Ed.), District wise soil test based fertilizer and manure recommendations for balanced nutrition of crops (Indian Institute of Soil Science, Bhopal, 2012).

[28] Anon, in Progress report of the All India Coordinated Research Project for investigation on Soil Test Crop Response Correlation, (Tamil Nadu Agricultural University, Coimbatore, Tamil Nadu, India, 2012), 28-44.

[29] R. Santhi, R. Natesan, G. Selvakumari, Soil Test Crop Response Correlation Studies under integrated plant nutrition system for onion (Allium cepa L. var. aggregatum) in Inceptisol of Tamil Nadu. J.Indian Soc.Sci 50, 2002, 489-492.

[30] S. Saranya, R. Santhi, K. Appavu, K. Rajamani, Soil Test based integrated plant nutrition system for ashwagandha on Inceptisols. Indian J. Agric $\operatorname{Res} 46,2012,88-90$.

[31] Milap Chand, D.K. Benbi, D.S. Benipal, Fertilizer recommendations based on soil tests for yield targets of mustard and rapeseed and their validations under farmer's field conditions in Punjab. J.Indian. Soc. Soil Sci., 54(3), 2006, 316-321.

[32] R. Santhi, R. Natesan, S. Maragatham, V.P. Duraisamy, K.M. Sellamuthu, Pradip Dey and A. Subba Rao, A Handbook on Soil Test and Yield target based integrated fertilizer prescriptions, (TNAU, Coimbatore, 2012).

[33] M. Velayutham, G.R Maruthi Sankar, K.C.K. Reddy, in Annual Report of the All India Co-ordinated Research Project on Soil Test Crop Response correlation (ICAR), (Hyderabad, India, 1984), 621-642.

[34] K. Coumaravel, Soil test crop response correlation studies through integrated plant nutrition system for maize - tomato sequence, Doctoral diss, Tamil Nadu Agricultural University, Coimbatore, 2012. 